\title{
Joe Gusfield at UCSD
}

\author{
Chandra Mukerji ${ }^{1}$
}

Published online: 7 July 2016

(C) Springer Science+Business Media New York 2016

It is both a sad exercise and a pleasure to reflect on Joe Gusfield's legacy because it requires both remembering him and saying goodbye again. He seems so present in what I write, he remains a part of my life. But certainly, the period of talking with him about his life and ideas over lunch, or discussing the proper intellectual development of the UCSD Sociology Department is now over. So, there is now good reason to keep these parts of his life in memory through print.

Joe Gusfield was a dear friend, and my husband, Bennett Berger, and I spent a great deal of time with Joe and his wife, Irma. We went to baseball games, argued about books, danced in their living room, drank to discuss drinking, enjoyed Joe's bad puns and good jokes, celebrated anniversaries, participated in seminars and colloquia together, and doted on and complained about children. We seemed to do almost everything together. Irma even took some of my classes.

I was a great admirer of Joe's work, so being around him was important to me. Irma discouraged us from getting too deeply into ideas at parties, but we still talked. I subtly tested all my new early ideas out on him. In return, Joe gave me drafts of his papers to read, and recommended papers and books for me to study. We talked in our homes, and we talked in our offices or the hall. It was heaven for me. His sense that knowledge was performed and materially embodied fit well with Latour's approach to science studies, so when Bruno was visiting, the conversations were both deeper and full of laughter. But Joe had a greater understanding of the power of performance in political processes that appealed to me, so I watched in his conversations with Latour to see how each explored performance in distinctive ways.

In the Sociology Department, he built an intellectual culture which I admired then and appreciate more today. He felt it important to support a vigorous and dynamic form of qualitative sociology that was based on studies of cognition, culture and history. Joe hated orthodoxy, and wanted to make sociology a more sophisticated and dynamic field enriched by other disciplines, making fun of arguments about the boundaries of Sociology as performances of power. He not only championed interdisciplinarity, but

Chandra Mukerji

cmukerji@ucsd.edu 
thought about how subdisciplines could more productively communicate with each other. He was happy to live without a hegemonic paradigm, but he was not happy to let subfields in Sociology drift apart independently, and lose the opportunity to inform each other and move the field as a whole in new ways.

Giving reign to his interest in cultural analysis, Joe Gusfield pioneered an approach to performance studies well before it became fashionable. He fused social constructionist sociology with Burke's work on rhetoric and performance to forge a more complex understanding of everyday social performances, and the character of their power. Just the same fusion is being elaborated today by Jeffrey Alexander, and is a leading approach in cultural sociology. Joe's cultural approach to historical sociology provided precedents for many of the productive new directions in cultural analysis that are now giving life to vital developments in cultural historical sociology, such as the work of Geneviève Zubrzycki. As the blinders of disciplinary orthodoxy have come down and cultural sociology has gained importance and nuance, more sociologists are doing work of the sort Joe tried to nourish.

Joe Gusfield did pioneering work in part because he liked to view problems through multiple analytic frames, and he founded the sociology department at UCSD to foster this approach in qualitative sociology. UCSD was a good place to do this. UCSD had been established originally as only a graduate school in STEM fields, luring Nobel Prize scientists to the California coast to do their research without the burden of undergraduate instruction. Once the UC Regents determined that California should not have a UC campus without undergraduates, new departments in the social sciences and humanities had to be established, but they were expected to be small and unusual. UCSD physicists, chemists, and engineers wanted the newcomers to experiment, so they hired people like Joe who wanted to try something new. By specializing in qualitative sociology, the department under Joe's leadership could become world class in that one area, drawing together different subfields that did qualitative work to make this kind of Sociology more dynamic.

So, Sociology was established as a kind of service department at UCSD, but one with the charge to become great by trying something new. As part of the social sciences and humanities, members of the department were given heavier teaching loads than the scientists, carrying the burden of undergraduate instruction. But as marginal members of an institution driven toward innovation, faculty had a freedom that was breathtaking.

Joe Gusfield followed in the UCSD tradition of hiring senior faculty with major reputations, such as Aaron Cicourel, Jack Douglas, Bennett Berger, Fred Davis, Randy Collins, and Jackie Wiseman. They also hired wonderfully talented junior faculty, such as Mounira Charad, Kristin Luker, Bennetta Jules-Rosette, Ruben Rumbaut, and Bud Mehan - among many others. Everyone was interested in questions of culture, and each one addressed them from a distinct perspective. But the faculty generally did work in one or more of the three areas: historical sociology, symbolic interactionism, and cognitive sociology.

Each of the three areas in the curriculum was grounded in a different epistemic culture. Faculty members who came in as senior figures and used to being respected, ended up fighting viciously about their differences. And the junior faculty were loathe to choose sides too decisively. The result was many leaders, no followers. Each group practiced becoming dominant by arguing with the others. What Joe Gusfield realizedbut not everyone else did- was that their differences were intellectually productive. 
There were reasons for the debates to be politically fraught because the subfields worked from different assumptions about how to do good work. But Joe was interested in the fact that the qualitative approaches together allowed scholars to address most topics in sociology, and to describe social life from the macro to the micro.

Historical sociology, as I understood Joe to describe it, had been the foundation for grand theory in the field, and was now using comparative studies of institutions and political processes to understand regimes and regime change. Historical sociology at that point was mostly indebted to Marx. This was the 1970s. But sociologists also appreciated the power of history in shaping the canonical work of Weber and Durkheim. Comparative history was qualitative work at the grandest scale. It allowed Joe to think about social structure, class, and institutional power. He was delighted with the work of Theda Skocpol, Michael Mann and Chuck Tilly because these scholars addressed sociology with documents. But structural accounts of power and politics in history particularly ones influenced by Marx-tended to dismiss culture as epiphenomenal, and treat social regimes as real entities rather than constructs with cultural roots. So, Joe thought historical sociology could benefit from more attention to culture, and cultural sociologists could benefit from more historical understanding. So, Mounira Charrad, Tim McDaniel, Randy Collins, and I all were encouraged to think about these issues.

Symbolic interactionism was at the heart of Joe's way of thinking about sociology and dominated the department's hiring. He loved the behaviorism of George Herbert Mead, quoting Mead when he could. But Joe had a particularly political approach to constructivism. He was interested in practices of power, the construction of everyday practices that embodied, shaped, or changed institutional orders. Interaction to Joe was unfolding history, and had a dynamism that historians recognized having effects over time. He liked John Gagnon for sharing this view, and Joe, Bennett, and John often had happy and intense debates when Gagnon came to town. Most importantly to Joe, Erving Goffman had placed performance studies at the center of qualitative sociology. Interactions were not just made up at the moment, but were performances of familiar sorts. What interested Joe was what made some performances so powerful. So, he pushed symbolic interactionism toward studies of language, and particularly of rhetoric in Burke.

Joe Gusfield was interested in ethnomethodology and cognitive sociology because they made language practices central to sociology, and developed methods for looking at thought as semiotic action. He appreciated precise and hermeneutic qualities in the work of Harold Garfinkel but most of all, he was influenced by Aaron Cicourel who paid such careful attention to language in everyday performances. Aaron thought there were ways to understand how realities were built and interpreted in concrete practices, but he was unconvinced that sociologists knew how to do this. Aaron was contemptuous of what he saw as the sloppiness of symbolic interactionism, giving Joe great pleasure with his passion for methodological precision even though Joe was himself a symbolic interactionist. Thinking of language as a social practice pleased him because it provided qualitative sociologists with a point of reflexivity about their own practices in reading documents and writing up field notes, quoting them as truth. Cognitive sociology was linked to discourse analysis by Bud Mehan and Bennetta Jules-Rosette. Cognitive sociology was also a lure to UCSD for Karin Knorr-Cetina and Bruno 
Latour, both of whom stimulated interest in the sociology of science at UCSD, allowing Steven Shapin and Steve Epstein to later join the faculty in Sociology at UCSD.

The result of recognizing and reproducing the intellectual diversity within qualitative sociology at UCSD was that the department became a rich environment for thinking about culture. But due to the differences in epistemic culture among the groups, there were also many fights over ideas and how they should be implemented in the curriculum. Junior faculty like me, worried about getting tenure, faced the prospect of having their work evaluated by people who fundamentally disagreed about what mattered in sociology. Some junior faculty did not even stay in this contentious environment long enough to go up for tenure. For similar reason, graduate students had to put together committees very carefully to make sure the faculty would support their research and work together on their committees. To some extent, it was like living in a minefield. But the same differences also made intellectual life in the department active and compelling.

I thought it was like living in a family that liked to debate everything - the kind of family Joe came from. Joe liked a good intellectual tussle, and liked it at home as well as in the department. He enjoyed holding reading groups in his home, making intellectual debate part of everyday life. He was happiest when graduate students and faculty came over to talk about books influencing the field. The talk was impassioned, and often lasted for hours. He never asked us to go home, although maybe Irma did, but I remember staying late.

There were many ways in which Joe's approach to sociology at UCSD reflected his personal experience. He came from a poor Jewish family from Chicago. Like other Jewish families, its members were interested in practices of reading and debating the Torah. Joe's family was poor and undereducated, but believed in education. Like many poor families, his invested in one child who showed promise. This was Joe. Everyone in his family worked to help pay for him to go to the University of Chicago and get a first-class education. They made it possible for him to study the qualitative tradition of sociology, and learn to bridge social worlds and cultural logics to fit in.

Being upwardly mobile affected Joe's understanding of performance, and made him a social constructivist. He was clear that the professor, Joe Gusfield, had been socially constructed by his family, and could become different than them by learning new ways to act. This is why he quoted Mead all the time, pointing his finger up to heaven as though Mead's writing were sacred. Mead allowed him to understand what was happening to him as he left his poor neighborhood and became a professor. He needed to joke about the depth of his debt to Mead because it was not just disciplinary; it was emancipatory. It allowed Joe to feel and get his family to feel that there was nothing essentially different about him and other members of his family. He wasn't smarter or better, but he had learned to do things they could not. It wasn't that he thought he was a sham. Not more than others, he would suggest. But he was a firm believer in situational nature of social identities and the performative quality of identity practices. He performed his middle-class competence, and found it funny because he could tell you when and how he learned to speak with a more educated accent, and debate ideas in conventionally recognized academic ways. Viewing his own success as a social accomplishment, Joe was modest, and had a good laugh at his own and others' pretensions. Irma helped by laughing at all sociologists. 
I think Joe's interest in historical sociology and Marxist theory of history came from his deep personal knowledge of social class and its effects. Living on the south side of Chicago, he could see the contrast between the ghettoes and the University. And sharing his life and successes with his relatives in the Jewish area, he inhabited dual worlds of class himself. When he wrote on prohibition, he was particularly interested in the role of upper-class women in forming social policy, and when he wrote about drinking practices, he was particularly interested in how drinking practices contributed to the lives and conceptions of working class men. Thinking about the injuries of class that were apparent in his family also made Joe particularly interested in social justice. To do his part, he sought out women and minorities as tenure-track faculty, wanting to help them just as his family had helped him. The point of thinking historically about patterns of power was to understand historical change and make it, too.

Joe was also very influenced intellectually by his experiences in India where he taught and visited on numerous occasions and often for long periods of time. It made him sensitive to issues of race and colonialism. He talked about the cultural assumptions about Indian backwardness that had served colonialism and that still haunted the West. He confessed with shame to thinking of India as backward in spite of his egalitarian principles and commitment to relativism. He and Irma used to laugh and make fun of this, creating a mantra to mock themselves: "Western is Bestern." Joe was particularly impressed by the quality of intellectual life in India, and loved the passion with which educated elites debated ideas. He also became interested in literary practices in intellectual cultures, and gained his first insight into the importance of rhetoric while he was India. He thought that rhetorical moves gave ideas credibility, but they also could have the opposite effect. The rhetorical style used by Indian intellectuals in both speaking and writing made their ideas seem less impressive to Western readers. Growing up in a family that spoke Yiddish and learning to speak learned English, Joe already understood some ways language affected credibility. But he began to focus more firmly on rhetorical practices and questions of power and history while he was working in India.

To pursue this line of thought, Joe began by focusing on the work of Kenneth Burke. Kenneth Burke came to UCSD for the week as a distinguished visitor to campus, and Joe made every effort to see him whenever he could. Burke was a drinker, and Joe could drink like the best of them, so they drank and talked late into the night. Joe wrote about Kenneth Burke afterwards, trying to show how performance approaches to sociology could be reinvigorated by paying attention to rhetorical performance. Joe used this analytic approach in his work on drinking driving, treating court procedures as rhetorical performances. In debates about legal cases, reality was in play, up for grabs. Lawyers engaged in rhetorical contests to spin reality. Joe argued that most of politics took place in the same way. People tried to make their positions plausible not simply with the way they spoke, but also with the stages on which they performed.

I wish Joe were alive today to enjoy contemporary sociology of culture. It has moved in his direction and in other directions that he would appreciate, but grumble about, too. Historical sociology of culture has flourished and become wonderfully sophisticated in the last five years or so, and Joe would have added an important voice to this work. And I wish the Joe had remained active in sociology long enough to fight against the turn to orthodoxy in the field that I think has hobbled sociology for the past two decades. Joe understood that sociology had developed out of a particular historical 
moment, and he strove to help sociology change with history and maintain its relevance as its institutional power waned in the US.

Building a curriculum based on three different epistemic cultures was a way for Joe to refuse orthodoxy, and embrace doubt and creative innovation. For Joe, the important part of being a sociologist was to try to understand what made social life the way it was, and to think about social justice and how it might be achieved. The point was to make a field that addressed the humanity of people and the inhumanity of institutional power. He was a poker player who kept in mind that social life was a game and watched how money and bluffing affected outcomes. If only he could talk to about politics now, and the power of the bluff.

Joe wanted to renew sociology by staying true to its traditions at the University of Chicago, but still raising new questions about social life and trying to address them with from different perspectives. He liked to emphasize and learn from the differences among subfields, and happily explored other fields where he thought he might find resources for improving sociology. It was a fine goal, and I hope others will recognize its importance and maintain this passion both for the field and the diversity in it. 